\title{
EVALUASI LAPORAN KINERJA INSTITUSI PADA BADAN PERENCANAAN PEMBANGUNAN DAERAH (BAPPEDA) PROVINSI SULAWESI UTARA
}

\author{
Lucyana Aprillya Simanjuntak ${ }^{1}$, Hendrik Manossoh $^{2}$, Sintje Rondonuwu ${ }^{2}$ \\ ${ }^{1,2}$ Jurusan Akuntansi, Fakultas Ekonomi dan Bisnis, Universitas Sam Ratulangi, Jl. Kampus Bahu, Manado, \\ 95115, Indonesia \\ ${ }^{1}$ E-mail: lucyanaaprillya@gmail.com
}

\begin{abstract}
The performance report of government agencies performance is a form of accountability in presenting, reporting and disclosing the mission of the agency in the form of activities and activities that are the responsibility of the stakeholders who have the right and authority to request such accountability. Performance Reports presented in accordance with applicable regulations can be utilized to make a decision and steps to be taken in the future in improving agency performance. This study aims to determine the performance report of BAPPEDA has been presented in accordance with the regulations and assess the work achievements of BAPPEDA. The analytical method used is descriptive qualitative. The results of this study indicate that the BAPPEDA performance report is in accordance with the guidelines of the State administration agency (LAN) and the BAPPEDA performance achievements are in good class so that the BAPPEDA performance report can be used for decision making.
\end{abstract}

Keywords: LAKIN; accountability; performance; information; good governance

\section{PENDAHULUAN}

Kinerja instansi pemerintah merupakan gambaran mengenai pencapaian sasaran ataupun tujuan instansi pemerintah sebagai penjabaran dari visi, misi, dan strategi instansi yang mengindikasikan tingkat keberhasilan dan kegagalan pelaksanaan kegiatan-kegiatan sesuai dengan program dan kebijakan yang ditetapkan. Terselenggaranya pemerintahan yang baik merupakan prasyarat bagi pemerintahan dalam mewujudkan aspirasi masyarakat dan mencapai cita-cita bangsa dan Negara. Untuk itu, diperlukan pengembangan dan penerapan sistem pertanggungjawaban yang terukur dan legitimasi sehingga penyelenggara pemerintah dan pembangunan berlangsung secara berdaya guna, berhasil guna, bersih, dan bertanggungjawab serta bebas dari budaya kolusi, korupsi, dan nepotisme.

Dengan adanya tuntutan untuk terwujudnya tata kelola kepemerintahan yang baik yang selanjutnya disebut good governance, maka pemerintahan kembali dituntut untuk mampu menata kembali pola-pola kerja yang dilakukan selama ini. Dengan kata lain, tuntutan untuk terwujudnya pemerintahan yang baik ini, pemerintah diharapkan mampu menjaga sinergitas dengan komponen pemerintahan lainnya, yaitu masyarakat dan dunia usaha. Oleh karena itu, pemerintah dalam menjalankan aktivitas pemerintahannya dituntut untuk selalu transparan dan akuntabel.

Dalam rangka upaya menyelenggarakan pemerintahan yang bersih dan bebas Kolusi, Korupsi, dan Nepotisme (KKN), sekaligus sebagai pemenuhan atas tuntutan publik atas akuntabilitas kinerja pemerintah menerapkan Sistem Akuntabilitas Kinerja Instansi Pemerintah (SAKIP) yang terintegrasi dengan sistem perencanaan strategis, sistem anggaran, dan sistem akuntansi pemerintahan yang mulai diberlakukan sejak diterbitkannya Instruksi Presiden Nomor 7 Tahun 1999 yang diperbaharui dengan Peraturan Pemerintah Nomor 8 Tahun 2006 yang menghasilkan Laporan Kinerja (LAKIN) sebagai luarannya. Sistem ini mengukur keberhasilan maupun kegagalan program dan kegiatan dengan melakukan evaluasi 
tingkat capaian kinerja yang dapat direalisasikan sebagai imbalan atas penggunaan anggaran dan umpan balik atas kendala pencapaian guna perbaikan strategi di masa yang akan datang.

Pemberlakuan sistem ini bertujuan memberikan arah pengukuran kinerja instansi pemerintahan guna menentukan apakah pelaksanaan kegiatan sudah dilaksanakan dengan baik atau belum dengan adanya indikator yang bisa menilai kinerja, visi, misi dan tujuan yang ingin dicapai oleh suatu organisasi pemerintahan. Oleh karena itu, dengan terbitnya Peraturan Presiden Nomor 29 tahun 2014 dan Peraturan Menteri Pendayagunaan Aparatur Negara dan Reformasi Birokrasi Republik Indonesia Nomor 53 Tahun 2014 dalam rangka meningkatkan pelaksanaan pemerintah yang lebih berdaya guna, berhasil, bersih dan bertanggungjawab, maka Laporan Kinerja (LAKIN) perlu dibuat agar dapat diketahui kemampuan instansi pemerintah di Indonesia dalam mencapai visi, misi dan tujuan yang telah ditetapkan.

Permasalahan organisasi pemerintah yaitu adanya konsep pemahaman aparatur pemerintah bahwa ukuran keberhasilan dan kegagalan dalam menjalankan tugas pokok dan fungsinya hanya bertumpu pada kemampuan instansi dalam menyerap anggaran yang dialokasikan, dalam arti bahwa keberhasilan instansi hanya ditekankan pada aspek masukan (input) tanpa melihat luaran (output) maupun dampaknya yang kemungkinan masih jauh dari standar, padahal untuk mengetahui keberhasilan maupun kegagalan organisasi seluruh aktivitas organisasi harus dapat diukur dan indikator pengukuran tidak hanya berdasarkan pada masukan tapi juga berdasarkan pada luaran atau manfaat dari suatu program/kegiatan.

Reviu Laporan Kinerja (LAKIN) pada BAPPEDA ini sangat penting dilakukan untuk mengetahui bagaimana tingkat kesesuaian dan ketetapan dalam penyusunan LAKIN dengan pedoman yang berlaku. Ketidaksesuaian dan ketidaktepatan penyusunan LAKIN pada pedoman yang diterbitkan oleh Lembaga Administrasi Negara (LAN) No. 239/IX/6/8/2003 tahun 2003 tentunya akan berdampak pada akuntabilitas kinerja pemerintah daerah sebagai perwujudan kewajiban suatu instansi pemerintah untuk mempertanggungjawabkan keberhasilan dan kegagalan pelaksanaan misi organisasi dalam mencapai sasaran dan tujuan yang telah ditetapkan melalui sistem pertanggungjawaban periodik.

Mengingat integritas, kredibilitas sangat penting pada lembaga pemerintahan untuk menghasilkan mutu yang baik salah satunya Badan Perencanaan Pembangunan Daerah yang menunjang kinerja Pemerintah Provinsi Sulawesi Utara harus akuntabel dalam mengelola institusinya. Evaluasi laporan kinerja dilakukan guna menentukan apakah penyajian laporan kinerja yang tercantum dalam LAKIN telah disajikan sesuai peraturan yang berlaku.

\section{TINJAUAN PUSTAKA}

Akuntansi. Surjaweni (2015:1) mendefinisikan akuntansi sebagai suatu aktivitas yang terdiri dari mencatat, mengklasifikasikan, dan melaporkan kejadian atau transaksi ekonomi yang akhirnya akan menghasilkan suatu informasi keuangan yang dibutuhkan oleh pihak-pihak tertentu untuk pengambilan keputusan. Kartikahadi et al. (2016:3) menyatakan bahwa akuntansi adalah suatu sistem informasi keuangan yang bertujuan untuk menghasilkan dan melaporkan informasi yang relevan bagi berbagai pihak yang berkepentingan. Menurut Bahri (2016:2), akuntansi adalah seni pencatatan, pengikhtisaran, dan pelaporan dari suatu transaksi dengan cara sedemikian rupa, sistematis dari segi isi, dan berdasarkan standar yang diakui umum, dan oleh karena itu pihak yang berkepentingan atas perusahaan dapat mengetahui posisi keuangan perusahaan serta hasil operasi pada setiap waktu yang diperlukan sehingga dapat mengambil keputusan atas pemilihan alternatif di bidang ekonomi.

Akuntansi pemerintahan. Sujarweni (2015:18) menyatakan bahwa akuntansi pemerintahan adalah akuntansi yang terkait dengan bidang keuangan Negara mulai dari anggaran sampai dengan pelaksanaan dan pelaporannya termasuk pengaruh yang ditimbulkannya. Peraturan Pemerintah Nomor 71 Tahun 2010 menyatakan bahwa sistem akuntansi pemerintahan adalah rangkaian sistematik dari prosedur, penyelenggara, peralatan, 
dan elemen lain untuk mewujudkan fungsi akuntansi sejak proses analisis transaksi hingga pelaporan keuangan di lingkungan organisasi pemerintah. Dengan demikian, akuntansi pemerintahan merupakan persyaratan yang mempunyai kekuatan hukum dalam upaya meningkatkan kualitas laporan keuangan pemerintah di Indonesia. Akuntansi pemerintahan adalah prinsip-prinsip akuntansi yang diterapkan dalam menyusun dan menyajikan laporan keuangan pemerintah.

Akuntansi sektor publik. Menurut Malahika et al. (2018), akuntansi sektor publik adalah suatu aktivitas dalam bidang publik yang menyediakan suatu bentuk laporan yang terjadi karena adanya transaksi ekonomi atau kegiatan mencatat yang menghasilkan suatu laporan sebagai bentuk pertanggungjawaban keuangan di bidang publik. Menurut Erlina et al. (2015), akuntansi sektor publik adalah akuntansi yang dipakai untuk mencatat peristiwa ekonomi dalam organisasi non profit atau nirlaba.

Pengukuran kinerja. Menurut Mahsun (2007) dalam Gare (2017:8), pengukuran kinerja (performance measurement) adalah suatu proses penilaian kemajuan pekerjaan terhadap tujuan dan sasaran yang telah ditentukan sebelumnya termasuk informasi atas efisiensi penggunaan sumber daya dalam menghasilkan barang dan jasa, kualitas barang, dan jasa (seberapa baik barang dan jasa diserahkan kepada pelanggan dan seberapa jauh kepuasan pelanggan yang dihasilkan), hasil kegiatan dibandingkan dengan maksud yang diinginkan dan efektivitas tindakan dalam mencapai tujuan. Menurut Zubair dan Koton (2016:11), pengukuran kinerja adalah suatu proses penilaian kemajuan pekerjaan terhadap pencapaian tujuan dan sasaran yang telah ditentukan termasuk informasi atas efisiensi penggunaan sumber daya dalam menghasilkan barang dan jasa, kualitas barang dan jasa, perbandingan hasil kegiatan dengan target, dan efektivitas tindakan dalam mencapai tujuan.

Akuntabilitas. Tanjung (2014:11) menyatakan bahwa akuntabilitas adalah proses untuk mempertanggungjawabkan pengelolaan sumber daya serta pelaksanaan kegiatan suatu entitas pelaporan dalam mencapai tujuan yang telah ditetapkan secara periodik. Menurut Lukito (2014:2), akuntabilitas adalah bentuk kewajiban penyelenggara kegiatan publik untuk dapat menjelaskan dan menjawab segala hal menyangkut langkah dari seluruh keputusan dan proses yang dilakukan, serta pertanggungjawaban atas hasil dan kinerjanya. Menurut Djalil (2014:63), akuntabilitas merupakan suatu konsep etika yang begitu dekat dengan administrasi publik pemerintahan (lembaga eksekutif pemerintah, lembaga legislatif parlemen, dan lembaga yudikatif) yang mempunyai beberapa arti, seperti dipertanggungjawabkan (responsibility), yang dapat dipertanyakan (answerbility), yang dapat dipersalahkan (blameworthiness), dan yang mempunyai keterkaitan dengan harapan yang dapat menerangkan salah satu aspek administrasi publik pemerintah.

Laporan Kinerja (LAKIN). Keputusan Kepala Lembaga Administrasi Negara No. 239/IX/6/8/2003 mengimplikasikan bahwa LAKIN sebagai salah satu bentuk pertanggungjawaban instansi pemerintahan kepada masyarakat sebagai pemegang kedaulatan tertinggi negara sesuai dengan ketentuan peraturan perundang-undangan yang berlaku dimana setiap instansi pemerintah berkewajiban untuk menyiapkan, menyusun, dan menyampaikan laporan kinerja secara tertulis, periodik dan melembaga. Bentuk LAKIN berdasarkan Keputusan Kepala Lembaga Administrasi Negara No. 239/IX/6/8/2003 adalah:

a. Ikhtisar Eksekutif. Bagian ini menyajikan tujuan dan sasaran yang telah ditetapkan dalam rencana stratejik serta sejauh mana instansi pemerintah mencapai tujuan dan sasaran utama tersebut, serta kendala-kendala yang dihadapi dalam pencapaiannya. Selain itu, dalam bagian ini disebutkan langkah-langkah apa yang telah dilakukan untuk mengatasi kendala tersebut dan langkah antisipatif untuk menanggulangi kendala yang mungkin akan terjadi pada tahun mendatang.

b. Pendahuluan. Bagian ini menjelaskan hal-hal umum tentang instansi serta uraian singkat mandat apa yang dibebankan kepada instansi (gambaran umum tupoksi). 
c. Rencana stratejik. Bagian ini menyajikan gambaran singkat mengenai rencana stratejik dan rencana kinerja. Awal bagian ini menyajikan gambaran secara singkat sasaran yang akan dicapai oleh instansi pada tahun yang bersangkutan serta bagaimana kaitannya dengan capaian visi dan misi instansi.

d. Akuntabilitas kinerja. Bagian ini menyajikan uraian hasil pengukuran kinerja, evaluasi, dan analisis akuntabilitas kinerja, termasuk menguraikan keberhasilan dan kegagalan, hambatan, kendala, dan permasalahan yang dihadapi serta langkah-langkah antisipatif yang akan diambil. Selain itu, dilaporkan pula akuntabilitas keuangan dengan cara menyajikan alokasi dan realisasi anggaran bagi tupoksi atau tugas-tugas lainnya, termasuk analisis tentang capaian indikator kinerja efisiensi.

e. Penutup. Bagian ini mengemukakan tinjauan umum tentang keberhasilan dan kegagalan, permasalahan, dan kendala utama terkait kinerja instansi yang bersangkutan serta strategi pemecahan masalah yang akan dilaksanakan di tahun mendatang.

f. Lampiran-lampiran. Bagian ini menyajikan bentuk penjelasan lebih lanjut, perhitunganperhitungan, gambar, dan aspek pendukung seperti SDM, sarana prasarana, metode dan aspek lain dan data yang relevan, keputusan-keputusan atau peraturan-peraturan dan perundang-undangan tertentu yang merupakan kebijakan yang ditetapkan dalam rangka pencapaian visi, misi, tujuan dan sasaran.

Metode Sturges. Berdasarkan alat analisis yang digunakan oleh Yusrianti dan Safitri (2015), maka dapat diinterpretasikan bahwa metode ini sebagai adalah aturan untuk menentukan seberapa luas dipilih data dalam suatu grafik batang pada histogram dimana metode ini menggunakan jumlah kelas interval dalam distribusi frekuensi. Yusrianti dan Safitri (2015) menerapkan kriteria atau kelas capaian dengan teknis: (1) menentukan rentang, yaitu data terbesar dikurangi data terkecil; (2) menyusun kelas capaian dengan rumus $\sum \mathrm{K}=1$ $+3,3 \log \mathrm{n}$, dimana $\sum \mathrm{K}$ adalah banyaknya kelas dan $\mathrm{n}$ adalah jumlah data; (3) menentukan panjang kelas interval/lebar kelas dengan cara membagi rentang data (range) dengan jumlah kelasnya; dan (4) membuat tabel distribusi frekuensi dengan cara menjumlahkan batas bawah masing-masing kelas dengan intervalnya dimulai dari kelas terendah sampai dengan kelas tertinggi yang bertujuan untuk mengklasifikasikan angka indeks yang telah diperoleh kedalam kategori kelas dan kriteria penilaian.

\section{METODE PENELITIAN}

Penelitian ini menggunakan pendekatan kualitatif dengan metode analisis deskriptif dengan sumber data bersifat primer yang berasal dari Badan Perencanaan Pembangunan Daerah Provinsi Sulawesi Utara guna memperoleh data kualitatif berupa gambaran umum objek penelitian seperti sejarah instansi, profil instansi, struktur instansi, tugas dan tanggungjawab, serta dokumen Rencana Pembangunan Jangka Menengah Daerah Provinsi Sulawesi Utara, Laporan Kinerja (LAKIN) Badan Perencanaan Pembangunan Daerah Provinsi Sulawesi Utara tahun 2018, dan Pedoman Penyusunan Pelaporan Akuntabilitas Kinerja Instansi Pemerintah berdasarkan Keputusan Kepala Lembaga Administrasi Negara No. 239/IX/6/8/2003.

\section{HASIL PENELITIAN DAN PEMBAHASAN}

\subsection{Hasil penelitian}

Laporan Kinerja (LAKIN) dari Badan Perencanaan Pembangunan Daerah (BAPPEDA) Provinsi Sulawesi Utara tahun 2018 terdiri dari:

- Ikhtisar eksekutif. Bagian ini menjelaskan tujuan dan sasaran utama yang hendak dicapai oleh BAPPEDA, dijelaskan secara singkat kinerja BAPPEDA tahun 2018, serta kendalakendala yang dihadapi dalam pencapaiannya.

- Pendahuluan. Bagian ini menjelaskan secara singkat tentang latar belakang atau hal-hal 
umum tentang Badan Perencanaan Pembangunan Daerah (BAPPEDA) Provinsi Sulawesi Utara, tugas pokok dan fungsi, aspek strategis BAPPEDA serta struktur organisasi BAPPEDA.

- Rencana stratejik. Bagian ini menjelaskan secara ringkas dokumen perencanaan yang menjadi dasar pelaksanaan program, kegiatan dan anggaran BAPPEDA tahun 2018 meliputi rencana strategis Badan Perencanaan Pembangunan Daerah Provinsi Sulawesi Utara tahun 2016-2021dan penetapan kinerja.

- Akuntabilitas kinerja. Bagian ini menjelaskan analisis pencapaian kinerja BAPPEDA dikaitkan dengan pertanggungjawaban publik terhadap pencapaian sasaran strategis untuk tahun 2018.

- Penutup. Bagian ini menjelaskan kesimpulan menyeluruh dari Laporan Kinerja BAPPEDA tahun 2018 dan menguraikan upaya pemecahan masalah yang diperlukan bagi perbaikan kinerja dimasa mendatang.

- Lampiran. Bagian ini menguraikan keputusan-keputusan atau peraturan-peraturan dan perundangundangan tertentu yang merupakan kebijakan yang ditetapkan dalam rangka pencapaian visi, misi, tujuan dan sasaran serta diuraikan daftar gambar dan daftar tabel.

\subsection{Pembahasan}

Evaluasi LAKIN BAPPEDA terkait bentuk penyusunan LAKIN menurut Pedoman Penyusunan Pelaporan Akuntabilitas Kinerja Instansi Pemerintah. Laporan Kinerja (LAKIN) menurut Keputusan Kepala Lembaga Administrasi Negara No. 239/IX/6/8/2003 adalah:

- Ikhtisar eksekutif. Pada bagian ini disajikan tujuan dan sasaran yang telah ditetapkan dalam rencana stratejik serta sejauh mana instansi pemerintah mencapai tujuan dan sasaran utama tersebut, serta kendala-kendala yang dihadapi dalam pencapaiannya. Bagian ini juga menyebutkan langkah-langkah apa yang telah dilakukan untuk mengatasi kendala tersebut dan langkah antisipatif untuk menanggulangi kendala yang mungkin akan terjadi pada tahun mendatang. LAKIN BAPPEDA tahun 2018 menguraikan tentang tujuan dan sasaran yang telah ditetapkan dalam rencana stratejik serta sejauh mana instansi pemerintah mencapai tujuan dan sasaran utama tersebut, serta kendala-kendala yang dihadapi dalam pencapaiannya dan langkah-langkah apa yang telah dilakukan untuk mengatasi kendala tersebut. Hasil evaluasi menunjukkan bahwa ikhtisar eksekutif BAPPEDA sudah sesuai dengan peraturan yang ada yaitu format penyusunan LAKIN menurut Keputusan Kepala Lembaga Administrasi Negara No. 239/IX/6/8/2003.

- Pendahuluan. Pada bagian ini dijelaskan hal-hal umum tentang instansi serta uraian singkat mandat apa yang dibebankan kepada instansi (gambaran umum tupoksi). LAKIN BAPPEDA tahun 2018 menguraikan mengenai hal-hal umum tentang instansi berupa sejarah BAPPEDA, visi dan misi BAPPEDA, struktur organisasi BAPPEDA dan tujuan, pokok serta fungsi BAPPEDA. Hasil evaluasi menunjukkan bahwa penyusunan pendahuluan telah sesuai dengan Keputusan Kepala Lembaga Administrasi Negara No. 239/IX/6/8/2003.

- Rencana stratejik. Pada bagian ini disajikan gambaran singkat mengenai rencana stratejik dan Rencana Kinerja. Pada awal bagian ini disajikan gambaran secara singkat sasaran yang ingin dicapai instansi pada tahun yang bersangkutan serta bagaimana kaitannya dengan capaian visi dan misi instansi. Secara rinci, bagian ini memuat:

a. Rencana stratejik, uraian singkat tentang rencana stratejik instansi, mulai dari visi, misi, tujuan, sasaran serta kebijakan dan program instansi.

b. Rencana kinerja, disajikan rencana kinerja pada tahun yang bersangkutan, terutama menyangkut kegiatan-kegiatan dalam rangka mencapai sasaran sesuai dengan program pada tahun tersebut, dan indikator keberhasilan pencapaiannya.

LAKIN BAPPEDA tahun 2018 menguraikan informasi tentang gambaran singkat 
mengenai rencana stratejik dan rencana kinerja serta gambaran secara singkat sasaran yang ingin diraih instansi pada tahun yang bersangkutan serta bagaimana kaitannya dengan capaian visi, misi instansi dan 8 (delapan) rencana strategi BAPPEDA untuk tahun 2016-2021 serta 19 program rencana kinerja untuk tahun 2018. Hasil evaluasi menunjukkan bahwa penyusunan rencana stratejik telah sesuai dengan Keputusan Kepala Lembaga Administrasi Negara No. 239/IX/6/8/2003.

- Akuntabilitas kinerja. Pada bagian ini disajikan uraian hasil pengukuran kinerja, evaluasi dan analisis akuntabilitas kinerja, termasuk di dalamnya menguraikan secara sistematis keberhasilan dan kegagalan, hambatan, kendala, dan permasalahan yang dihadapi serta langkah-langkah antisipatif yang akan diambil. Bagian ini juga melaporkan pula akuntabilitas keuangan dengan cara menyajikan alokasi dan realisasi anggaran bagi tupoksi atau tugas-tugas lainnya, termasuk analisis tentang capaian indikator kinerja efisiensi. LAKIN BAPPEDA tahun 2018 menguraikan secara ringkas kinerja BAPPEDA tahun 2018 serta laporan akuntabilitas keuangan BAPPEDA dengan mencantumkan alokasi APBN sejumlah Rp. 1.354.491.000 dan realisasi dana APBN BAPPEDA tahun 2018 sejumlah 1.346.022.120. Hasil evaluasi menunjukkan bahwa penyusunan akuntabilitas kinerja telah sesuai dengan Keputusan Kepala Lembaga Administrasi Negara No. 239/IX/6/8/2003.

- Penutup. Bagian ini mengemukakan tinjauan secara umum tentang keberhasilan dan kegagalan, permasalahan dan kendala utama yang berkaitan dengan kinerja instansi yang bersangkutan serta strategi pemecahan masalah yang akan dilaksanakan ditahun mendatang. LAKIN BAPPEDA menguraikan tinjauan secara umum tentang keberhasilan dan kegagalan, permasalahan dan kendala utama yang berkaitan dengan kinerja BAPPEDA dan mencantumkan 5 upaya pemecahan masalah yang akan dilaksanakan ditahun mendatang. Hasil evaluasi menunjukkan bahwa penyusunan penutup telah sesuai dengan Keputusan Kepala Lembaga Administrasi Negara No. 239/IX/6/8/2003.

- Lampiran-lampiran. Bagian ini memuat penjelasan lebih lanjut, perhitungan-perhitungan, gambar, dan aspek pendukung seperti SDM, sarana prasarana, metode, dan aspek lain dan data yang relevan, keputusan-keputusan atau peraturan-peraturan dan perundangundangan tertentu yang merupakan kebijakan yang ditetapkan dalam rangka pencapaian visi, misi, tujuan, dan sasaran. Hasil evaluasi menunjukkan bahwa penyusunan lampiran laporan telah sesuai dengan Keputusan Kepala Lembaga Administrasi Negara No. 239/IX/6/8/2003. LAKIN BAPPEDA menguraikan keputusan-keputusan atau peraturanperaturan dan perundangundangan tertentu yang merupakan kebijakan yang ditetapkan dalam rangka pencapaian visi, misi, tujuan, dan sasaran serta diuraikan daftar gambar dan daftar tabel. Hasil evaluasi menunjukkan bahwa penyusunan lampiran laporan telah sesuai dengan Keputusan Kepala Lembaga Administrasi Negara No. 239/IX/6/8/2003.

Evaluasi Capaian Kinerja BAPPEDA tahun 2018. Evaluasi capaian kinerja Badan Perencanaan Pembangunan Daerah Provinsi Sulawesi Utara tahun 2018 dalam penelitian ini menggunakan metode Sturges yang menilai evaluasi capaian program kinerja dari Badan Perencanaan Pembangunan Daerah tahun 2018. Angka indeks pencapaian program kinerja di BAPPEDA diperoleh dari dokumen LAKIN BAPPEDA, dimana nilai indeks tertinggi sebesar $100 \%$ dan terendah adalah sebesar $81 \%$. Berdasarkan matriks penilaian kemudian disusun kelas yang mengklasifikasikan data indeks ke dalam beberapa kategori kelas sehingga terbentuk pemeringkatan pada capaian program kinerja. Dengan menggunakan pendekatan STURGESS dapat ditentukan jumlah kelas sebagai berikut:

$$
\begin{aligned}
\sum \mathrm{K} & =1+3,3 \log \mathrm{n} \\
\sum \mathrm{K} & =1+3,3 \log 19 \\
& =1+3,3(1,2787) \\
& =5
\end{aligned}
$$


Berdasarkan jumlah kelas maka dapat ditentukan rentang data (range) yang kemudian dibagi dengan jumlah kelas untuk memperoleh kelas interval (rentang data dibagi jumlah kelas). Berdasarkan perhitungan ((100-81)/5) maka diperoleh kelas interval sebesar 3.8 atau dibulatkan menjadi 4. Berdasarkan kelas interval yang telah ditentukan maka dapat disusun tabel distribusi frekuensi kelas pencapaian dan klasifikasi tiap-tiap kelas ke dalam kriteria penilaian. Data indeks pencapaian program kinerja BAPPEDA menunjukkan bahwa nilai terendah adalah 81 maka dibuat tabel frekuensi data dimulai dari 81. Penyusunan kelas disusun dengan menentukan kelas paling bawah yaitu kelas dengan angka indeks paling rendah, menentukan lebar masing-masing kelas, dan mengkategorikan kelas ke dalam kriteria penilaian tertentu berdasarkan angka indeks yang diperoleh. Kriteria penilaian yang digunakan pada 5 kelas yaitu buruk, sangat kurang baik, kurang baik, baik, dan sangat baik. Pendekatan Sturges menyarankan untuk membuat tabel distribusi frekuensi dimulai dengan menjumlahkan batas bawah masing-masing kelas dengan intervalnya, dimulai dari kelas terendah sampai dengan kelas tertinggi. Tabel 1 menunjukkan bahwa kelas yang memiliki frekuensi atau jumlah paling banyak terdapat di kelas baik yang memiliki interval kelas 93\%96\% dengan jumlah 9 program kinerja yang berada di kelas baik.

Tabel 1. Distribusi frekuensi data indeks pencapaian program kinerja BAPPEDA

\begin{tabular}{clc}
\hline Kelas interval & \multicolumn{1}{c}{ Kriteria } & Jumlah Program Kinerja BAPPEDA \\
\hline $81-84$ & Buruk & 1 \\
$85-88$ & Sangat kurang baik & 2 \\
$89-92$ & Kurang baik & 2 \\
$93-96$ & Baik & 9 \\
$97-100$ & Sangat baik & 5 \\
Total & & 19 \\
\hline
\end{tabular}

Sumber: Data olah, 2020

Tabel 2 menunjukkan klasifikasi tingkat pencapaian program kinerja di BAPPEDA berdasarkan distribusi frekuensi data indeks pencapaian program kinerja BAPPEDA.

Tabel 2. Klasifikasi tingkat pencapaian program kinerja di BAPPEDA

\begin{tabular}{|c|c|c|c|c|}
\hline Kelas & Kriteria & & Program Kinerja BAPPEDA & Indeks \\
\hline \multirow[t]{5}{*}{ Sangat baik } & $\begin{array}{l}97 \%- \\
100 \%\end{array}$ & 1 & $\begin{array}{l}\text { Program peningkatan pengembangan sistem pelaporan pencapaian } \\
\text { kinerja dan keuangan. }\end{array}$ & $100 \%$ \\
\hline & & 2 & Program perencanaan infrastruktur dan pengembangan wilayah. & $98 \%$ \\
\hline & & 3 & $\begin{array}{l}\text { Program perencanaan pengembangan wilayah strategis dan cepat } \\
\text { tumbuh. }\end{array}$ & $100 \%$ \\
\hline & & 4 & Program monitoring dan evaluasi perencanaan pembangunan daerah. & $100 \%$ \\
\hline & & 5 & $\begin{array}{l}\text { Program perencanaan peningkatan kinerja investasi, pendanaan dan } \\
\text { keuangan daerah serta kerjasama pembangunan. }\end{array}$ & $98 \%$ \\
\hline \multirow[t]{9}{*}{ Baik } & $93 \%-96 \%$ & 1 & Program perencanaan pembangunan ekonomi dan perdagangan. & $93 \%$ \\
\hline & & 2 & Program perencanaan perkotaan dan pedesaan. & $93 \%$ \\
\hline & & 3 & Program perencanaan tata ruang. & $95 \%$ \\
\hline & & 4 & Program kerjasama pembangunan. & $95 \%$ \\
\hline & & 5 & Program perencanaan SKPD. & $95 \%$ \\
\hline & & 6 & Program perencanaan pemerintahan, sosial dan budaya. & $93 \%$ \\
\hline & & 7 & Program perencanaan pembangunan daerah (bidang 1, 2, 3, 4). & $93 \%$ \\
\hline & & 8 & Program pelayanan administrasi perkantoran. & $95 \%$ \\
\hline & & 9 & Program perencanaan pembangunan kota-kota menengah dan besar. & $96 \%$ \\
\hline \multirow[t]{2}{*}{ Kurang baik } & $89 \%-92 \%$ & 1 & Program peningkatan kapasitas sumber daya aparatur. & $90 \%$ \\
\hline & & 2 & Program pengembangan wilayah perbatasan. & $90 \%$ \\
\hline \multirow{2}{*}{$\begin{array}{l}\text { Sangat } \\
\text { kurang baik }\end{array}$} & $85 \%-88 \%$ & 1 & Program peningkatan disiplin aparatur. & $85 \%$ \\
\hline & & 2 & Program penyelenggaraan hari-hari besar kenegaraan/kedaerahan. & $85 \%$ \\
\hline Buruk & $81 \%-84 \%$ & 1 & Program peningkatan sarana dan prasarana aparatur. & $81 \%$ \\
\hline
\end{tabular}


Berdasarkan Tabel 2, maka Gambar 1 menyajikan grafik histogram kinerja di BAPPEDA.

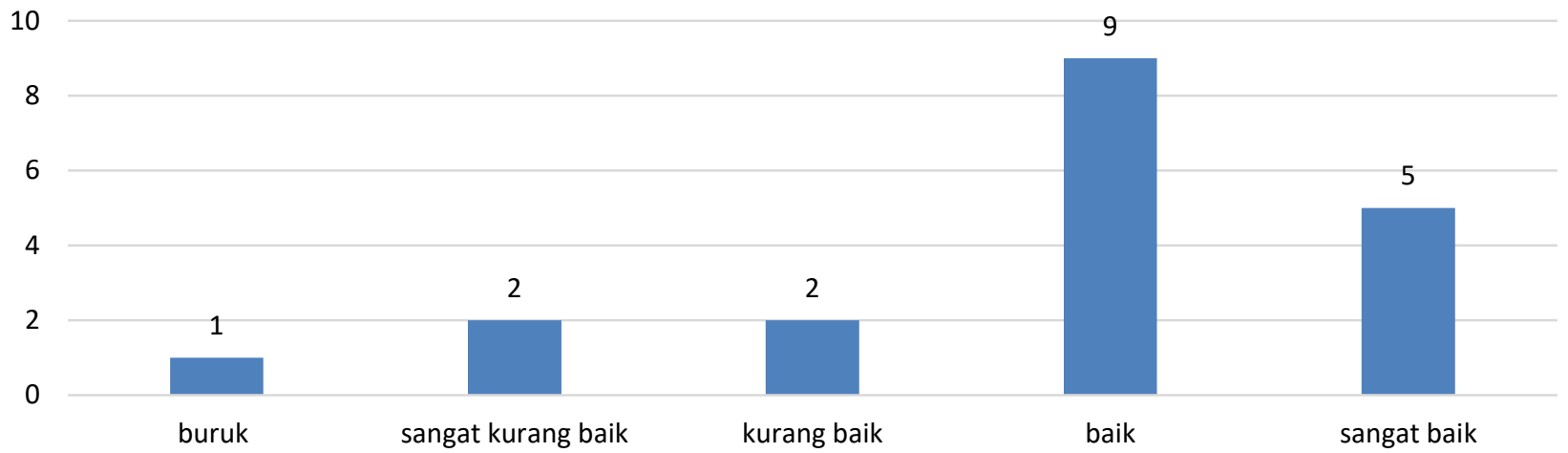

Gambar 1. Grafik histogram tingkat kinerja BAPPEDA

Berdasarkan Tabel 2 dan Gambar 1 maka secara umum pencapaian program kinerja SAKIP di BAPPEDA berada pada kelas/kriteria baik. Hasil obervasi dan wawancara dengan pihak BAPPEDA menunjukkan bahwa hampir keseluruhan program kinerja BAPPEDA sudah terealisasi sedangkan program kinerja yang tidak mencapai 100\% lebih banyak disebabkan karena masalah teknis.

\section{KESIMPULAN DAN SARAN}

\subsection{Kesimpulan}

Laporan kinerja (LAKIN) Badan perencanaan pembangunan daerah sudah sesuai dengan format penyusunan LAKIN yang telah ditetapkan oleh LAN yaitu pedoman LAKIN nomor 239/IX/6/8/2003. Laporan kinerja menunjukkan bahwa pencapaian kerja Badan Perencanaan Pembangunan Daerah dapat dikategorikan pada kelas/kriteria baik sehingga luaran ini dapat bermanfaat untuk pengambilan keputusan.

\subsection{Saran}

Berdasarkan hasil penelitian dalam mengevaluasi laporan kinerja maka saran penelitian ini agar Badan Perencanaan Pembangunan Daerah untuk dapat mempertahankan, meningkatkan dan mengembangkan kinerja pada tahun-tahun berikutnya.

\section{DAFTAR PUSTAKA}

Bahri, S. (2016). Pengantar akuntansi berdasarkan SAK ETAP dan IFRS. Yogyakarta: Penerbit Andi.

Djalil, R. (2014). Akuntabilitas keuangan daerah implementasi pasca reformasi. Jakarta: RM Books.

Erlina, Rambe, O. S., \& Rasdianto. (2015). Akuntansi keuangan daerah berbasis akrual. Jakarta: Salemba Empat.

Gare, M. E. (2017). Analisis pengukuran kinerja dengan menggunakan value for money (Studi kasus pada Klinik Adhiwarga Perkumpulan Keluarga Berencana Indonesia (PKBI) Daerah Istimewa Yogyakarta). Skripsi. Universitas Sanata Dharma. Yogyakarta. http://repository.usd.ac.id/11957/2/132114164_full.pdf

Kartikahadi, H., Sinaga, R. U., Syamsul, M., \& Siregar, S. V. (2016). Akuntansi keuangan berdasarkan SAK berbasis IFRS, Buku 1. Jakarta: Salemba Empat.

Lembaga Administrasi Negara Republik Indonesia. (2003). Keputusan Kepala Lembaga Administrasi Negara No. 239/IX/6/8/2003 tentang Pedoman Penyusunan Pelaporan Akuntabilitas Kinerja Instansi Pemerintah. 
Lukito, P. K. (2014). Membumikan transparansi dan akuntabilitas kinerja sektor publik: Tantangan berdemokrasi ke depan. Jakarta: Grasindo.

Malahika, M. J., Karamoy, H., \& Pusung, J. R. (2018). Penerapan Sistem Keuangan Desa (SISKEUDES) pada Organisasi Pemerintahan Desa (Studi kasus di Desa Suwaan Kecamatan Kalawat Kabupaten Minahasa Utara). Going Concern: Jurnal Riset Akuntansi, 13(04), 578-583. https://doi.org/10.32400/gc.13.04.21514.2018

Peraturan Menteri Pendayagunaan Aparatur Negara dan Reformasi Birokrasi Republik Indonesia Nomor 53 Tahun 2014 tentang petunjuk teknis perjanjian kinerja, pelaporan kinerja dan tata cara reviu atas laporan kinerja instansi pemerintah.

Peraturan Pemerintah Nomor 8 Tahun 2006 tentang pelaporan keuangan dan kinerja instansi pemerintah.

Peraturan Pemerintah Nomor 71 Tahun 2010 tentang Standar Akuntansi Pemerintah (SAP).

Peraturan Presiden Nomor 29 Tahun 2014 tentang Sistem Akuntabilitas Kinerja Instansi Pemerintah.

Sujarweni, V. M. (2015). Akuntansi sektor publik. Yogyakarta: Pustaka Baru Press.

Tanjung, A. H. (2014). Akuntansi, transparansi, dan akuntabilitas keuangan publik. Yogyakarta: BPFE UGM.

Yusrianti, H., \& Safitri, R. H. (2015). Implementasi Sistem Akuntabilitas Kinerja Instansi Pemerintah (SAKIP) pada Satuan Kerja Perangkat Daerah (SKPD) di lingkungan Pemerintah Kota Palembang. Jurnal Manajemen dan Bisnis Sriwijaya, 13(4), 545558. https://ejournal.unsri.ac.id/index.php/jmbs/article/view/3153

Zubair, E., \& Koton, Y. P. (2016). Pengelolaan Danau Limboto dalam perspektif kebijakan publik. Yogyakarta: Penerbit CV Budi Utama. 